\title{
A Study of Modernisation among Indian Youths across Gender \& Religions
}

\author{
Dr Alka Chaudhary ${ }^{1 *}$
}

\section{ABSTRACT}

Modernization is a process by which modern scientific knowledge covering all aspects of human life is introduced at varying degree, first in western civilization and later diffused to the non western word by different methods \& group with the ultimate purpose of achieving a better \& non satisfactory life in the broadest sense of the term, as accepted by the society concerned. The present study related to study the effect of sex and Religions on Modernisation. Modernization Scale designed by Raghvendra S. Singh, Amar Nath Tripathi and Ramjee Lal used for collecting primary data. Null hypothesis was tested and data analysis was done accordingly. 'C.R. test' applied to find out the significance of difference in the said trait of testing groups of the sample.

Keywords: Modernization Process, Indian Youth, Religions Role, Gender Wise Effects

Modernization The term 'modern' has many denotations and carries a heavy weight and connotations. Professor Jacobs (1971) explains modernization as "the maximization of the potential of the Society." In the words of Sayed Hussein Altas (1973) "Modernization is a process by which modern scientific knowledge covering all aspects of human life is introduced at varying degree, first in western civilization and later diffused to the non western word by different methods \& group with the ultimate purpose of achieving a better \& non satisfactory life in the broadest sense of the term, as accepted by the society concerned."

Indian society and its traditions In post-independent Indian tradition and modernity came into close interaction. The constitution of India is the best document of individual liberty, freedom and right of expression. It is also a manifestation of modern values and norms. The safeties and securities given to the weaker sections of society by the constitution present a blueprint for the attainment of modern Indian society. Sociologists did not pay any serious attention towards the attainment of this goal. They kept themselves engaged in the study of caste, family, kin and village. There is a massive literature on these aspects of society. Though the institutions of

\footnotetext{
${ }^{1}$ M.A, M.Phil, MBA Department, Krishna Institute of Engineering \& Technology, Muradnagar, Ghaziabad, India *Responding Author

Received: December 30, 2016; Revision Received: January 19, 2017; Accepted: January 30, 2017

(C) 2017 Chaudhary A; licensee IJIP. This is an Open Access Research distributed under the terms of the Creative Commons Attribution License (www.creativecommons.org/licenses/by/2.0), which permits unrestricted use, distribution, and reproduction in any Medium, provided the original work is properly cited.
} 


\section{A Study of Modernisation among Indian Youths across Gender \& Religions}

family, village and caste establish organic relation between various segments of society, the sociologists have restricted themselves to the study of the institution per section. It is only in the recently published poll project that wider linkages are identified which present a unified picture of Indian society. No constructs have been made by sociologists towards the building of a modern nation-state.

\section{Objectives:}

1. To Study the effect of modernization among Indian youth gender and religions wise.

2. To Study the effect of modernisation among Indian Youths across Gender \& religions (ranging in age 19-22 years) from Rohilkhand and Moradabad region.

\section{Hypotheses:}

1. There is no significant difference in the magnitude of modernization among Hindu, Muslim \& Sikh male youths.

2. There is no significant difference in the magnitude of modernization among Hindu, Muslim \& Sikh female youths.

3. There is no significant difference in the magnitude of modernization between male \& female Hindu youths.

4. There is no significant difference in the magnitude of modernization between male \& female Muslim youths.

5. There is no significant difference in the magnitude of modernization between male \& female Sikh youths.

\section{Variables:}

Sex and religion are the two independent variables and magnitude of modernization is the dependent variable. The various strata of the sample were matched with regard to important independent variables.

\section{Sample Design:}

It is a descriptive research design. A random sampling of six hundred (600) Hindu, Muslim and Sikh urban male and female of post graduate standard of age range 19-22 years, has been taken from Govt. and Govt. aided institutions of Rohilkhand and Moradabad Region. In this way 100 Hindu male, 100 Hindu female, 100 Muslim male and 100 Muslim female, 100 Sikh male and 100 Sikh female has been taken as the sample for the study. Sample design is as follows:

\section{Research Tools:}

Modernization Scale (Ms) The tool has been designed to measure the extents of modernity of Indian adolescents, by Raghvendra S. Singh, Amar Nath Tripathi and Ramjee Lal of Psychology Department. Buddha Post Graduate College, Kushinagar (Deoria) in 1987. The scale is reliable 


\section{A Study of Modernisation among Indian Youths across Gender \& Religions}

and valid for the adolescents (16-22 years) of both sex and of the urban and rural literate population.

\section{RESULTS AND DISCUSSION}

The collected data were processed and analysed keeping in view the purpose of the study. Each null hypothesis was tested one by one and data analysis was done accordingly. 'C.R. test' and 'Duncan's multiple range test' were applied to find out the significance of difference in the said trait of various testing groups of the sample.

Table - 1, Significance of Difference in the Magnitude of Modernization Among Hindu, Muslim and Sikh Male Youths

\begin{tabular}{|l|l|l|l|l|l|}
\hline $\begin{array}{l}\text { Nature of } \\
\text { Group }\end{array}$ & $\begin{array}{l}\text { (Number of } \\
\text { Subjects) N }\end{array}$ & Mean & $\begin{array}{l}\text { Sum of } \\
\text { Squares } \\
\text { (SS) }\end{array}$ & $\begin{array}{l}\text { Standard } \\
\text { Error of } \\
\text { Groups } \\
\text { (SC) }\end{array}$ & $\begin{array}{l}\text { Degree of } \\
\text { Freedom } \\
\text { (df) }\end{array}$ \\
\hline $\begin{array}{l}\text { Hindu Male } \\
\text { Youths }\end{array}$ & 105 & 114.276 & 107137.5 & & 303 \\
\hline $\begin{array}{l}\text { Muslim Male } \\
\text { Youths }\end{array}$ & 102 & 118.168 & 62538.38 & 23.2905 & \\
\hline $\begin{array}{l}\text { Sikh Male } \\
\text { Youths }\end{array}$ & 99 & 146.334 & 1758.29 & & \\
\hline
\end{tabular}

Table 1 indicate that the Hindu male $(\mathrm{M}=114.276)$ also differ significantly from Sikh male

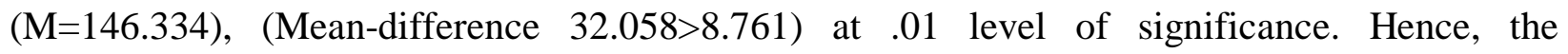
hypothesis framed in this regard, is rejected.

Table - 2, Area wise Mean Scores of Hindu, Muslim \& Sikh Female Youths on Modernization Scale

\begin{tabular}{|l|l|l|l|l|l|}
\hline \multirow{2}{*}{ Nature of Group } & \multirow{2}{*}{} & \multicolumn{4}{|c|}{ Areas of Modernization Scale } \\
\cline { 3 - 6 } & \multirow{2}{*}{ N } & $\begin{array}{l}\text { A } \\
\text { Socio } \\
\text { Religious }\end{array}$ & $\begin{array}{l}\text { B } \\
\text { Marriage }\end{array}$ & $\begin{array}{l}\text { C } \\
\text { Position of } \\
\text { Woman }\end{array}$ & $\begin{array}{l}\text { D } \\
\text { Education }\end{array}$ \\
\hline Hindu Female Youth & 95 & 123.020 & 108808.92 & & \multirow{2}{*}{291} \\
\hline Muslim Female Youth & 98 & 83.295 & 62181.60 & \\
\hline Sikh Female Youth & 101 & 162.085 & 21471.85 & \\
\hline
\end{tabular}

Table 2 indicate that the difference between Hindu \& Muslim female youths is significant. Likewise the difference between the mean scores of Hindu \& Sikh female youths is M2 M3 = 39.065 $>$ 9.9255. Thus, the difference between Hindu \& Sikh female is also significant. 
Table - 3, Significance of Difference in the Magnitude of Modernization of Hindu Male \& Female Youths

\begin{tabular}{|c|c|c|c|c|c|c|c|}
\hline $\begin{array}{l}\text { Nature of } \\
\text { Groups }\end{array}$ & $\mathbf{N}$ & Mean & $\begin{array}{l}\text { Mean } \\
\text { Difference }\end{array}$ & S. D. & S.ED. & $\begin{array}{l}\text { C. R. } \\
\text { Value }\end{array}$ & L. S \\
\hline $\begin{array}{l}\text { Hindu Male } \\
\text { Youths }\end{array}$ & 105 & 112.595 & \multirow[b]{2}{*}{4.135} & 32.182 & \multirow[b]{2}{*}{4.4767} & \multirow[b]{2}{*}{.9236} & \multirow[b]{2}{*}{ n.s. } \\
\hline $\begin{array}{l}\text { Hindu } \\
\text { Female } \\
\text { Youths }\end{array}$ & 95 & 116.73 & & 31.095 & & & \\
\hline
\end{tabular}

Table 3 shows total mean scores \& S.D.s of Hindu male and female youths on the modernization scale. It is quite evident that the difference between the male $(M=112.595)$ and female $(\mathrm{M}=116.73)$ youths is very less and negligible.

Table - 4, Significance of Difference in the Attitude towards Modernization of Muslim Male \& Female Youths

\begin{tabular}{|c|c|c|c|c|c|c|c|}
\hline $\begin{array}{l}\text { Nature of } \\
\text { Groups }\end{array}$ & $\mathbf{N}$ & Mean & \begin{tabular}{|l|} 
Mean \\
Difference
\end{tabular} & S. D. & S.ED. & \begin{tabular}{|l} 
C. R. \\
Value
\end{tabular} & L. $S$ \\
\hline $\begin{array}{l}\text { Muslim } \\
\text { Male } \\
\text { Youths }\end{array}$ & 102 & 116.538 & \multirow[t]{2}{*}{45.808} & 23.665 & \multirow[b]{2}{*}{3.4526} & \multirow[b]{2}{*}{13.2676} & \multirow[b]{2}{*}{.01} \\
\hline $\begin{array}{l}\text { Muslim } \\
\text { Female } \\
\text { Youths }\end{array}$ & 98 & 70.73 & & 25.105 & & & \\
\hline
\end{tabular}

The table 5 reveals that the mean scores of Muslim male youths are 116.538 while the mean scores of Muslim females on modernization scale are 70.73.

Table - 5, Significance of Difference in the Attitude towards Modernization of Sikh Male \& Female Youths

\begin{tabular}{|c|c|c|c|c|c|c|c|}
\hline $\begin{array}{l}\text { Nature of } \\
\text { Groups }\end{array}$ & $\mathbf{N}$ & Mean & \begin{tabular}{|l} 
Mean \\
Difference
\end{tabular} & S. D. & S.ED. & $\begin{array}{l}\text { C. R. } \\
\text { Value }\end{array}$ & L. $S$ \\
\hline $\begin{array}{l}\text { Sikh Male } \\
\text { Youths }\end{array}$ & 99 & 158.828 & \multirow{2}{*}{12.087} & 9.15 & \multirow{2}{*}{1.57} & \multirow{2}{*}{7.698} & \multirow{2}{*}{.01} \\
\hline $\begin{array}{l}\text { Sikh } \\
\text { Female } \\
\text { Youths }\end{array}$ & 101 & 170.915 & & 12.80 & & & \\
\hline
\end{tabular}




\section{A Study of Modernisation among Indian Youths across Gender \& Religions}

A perusal of table - 27 clearly demonstrates that the mean and S.D. on modernization scale are 158.828 and 9.15 respectively for the Sikh male youths, while these values on the other hand for females of Sikh religion are 170.915 and 12.80 respectively

\section{INTERPRETATION OF TABLES AND TESTING OF HYPOTHESIS}

\section{H01}

M1 M2= 3.892<6.386 (Calculated value)

Hence the difference between Hindu and Muslim male youths is not significant. On the other hand, the difference between the means of Muslim \& Sikh youths is 28.166, which is greater than the table value 8.392 (at .01 level of significance \& df 303), so it can be inferred that the Muslim male youths differ significantly from the Sikh male youths as far their modernity is concerned.

Likewise, the Hindu male ( $M=114.276)$ also differ significantly from Sikh male ( $M=146.334)$, (Mean-difference 32.058>8.761) at .01 level of significance. Hence, the hypothesis framed in this regard, is rejected.

\section{H02}

$$
\text { M1= 83.295 M2=123.020 M3=162.085 }
$$

Difference between mean scores of Muslim \& Hindu female youths

M1 M2 = $39.725>9.9255$ (Calculated Value)

Hence, the difference between Hindu \& Muslim female youths is significant. Like-wise the difference between the mean scores of Hindu \& Sikh female youths is M2 M3 = $39.065>$ 9.9255. Thus, the difference between Hindu \& Sikh female is also significant. Hence, the hypothesis framed in this context is acceptable.

\section{H03}

The total mean scores \& S.D.s of Hindu male and female youths on the modernization scale. It is quite evident that the difference between the male $(M=112.595)$ and female $(M=116.73)$ youths is very less and negligible. Hence, the hypothesis framed in this context is acceptable

\section{H04}

The S. Ds. of both the groups are 23.665 and 25.105 respectively. The difference is significant on .01 level of significance difference. Hence, the null hypothesis that there is no significant difference in the mean scores of Muslim male \& female youths on modernization scale is rejected.

\section{H05}

The mean and S.D. on modernization scale are 158.828 and 9.15 respectively for the Sikh male youths, while these values on the other hand for females of Sikh religion are 170.915 and 12.80 respectively. The SED value and C. R. value are also given in this table. The calculated C. R. value is 7.698 which is much greater than that of tabular C.R. value at .01 level of significance and df 198 (C. R. Tabular value 2.63). Hence, the mean difference between Sikh male \& female youths is found significant. Thus, the null hypothesis framed in this regard, is also rejected. 


\section{A Study of Modernisation among Indian Youths across Gender \& Religions}

\section{Acknowledgments}

The author appreciates all those who participated in the study and helped to facilitate the research process.

\section{Conflict of Interests}

The author declared no conflict of interests.

\section{REFERENCES}

Ammerman, N.T. Everyday Religion: Observing Modern Religious Lives; Oxford University Press: New York, NY, USA, 2007.

Arora, P.N., Bhartiya J.S \& Arora, Asha, "Sex difference in Modernization among Scheduled Caste adolescence, 82'nd Session of Indian Science Congress. Section of Psychology and Educational Sciences (Abstract) S.No. 46 P.50 1995

Bhardwaj, Krishna.1995. Social Change in India. New Delhi: Atlantic Publication.

Cadge, W.; Levitt, P.; Smilde, D. De-Centering and Decentering: Thinking Concepts and Methods in the Sociological Study of Religion. J. Sci. Stud. Relig. 2011, 50, 439-447.

Chakravarty, T.K. 1998. „Students Attitude towards Interact Marriagee, Australian Journal of Sociology.

Devendra, Agochiya. 2005. „Youth Development Programme at Cross-road “e Journal of Youth Development. Vol.1. July-Dec, 2005

Dube, S.C. 1973. Contemporary India and its Modernization. Delhi: Vikas Publishing House.

King, U. Some Reflections on Sociological Approaches to the Study of Modern Hinduism. Numen 1989, 36, 72-97.

Kirpal,P,(1976),’Youths and established culture New delhi. Sterling Publishers Pvt.Ltd.

Levy, H.J," Modernization and the structure of the societies, Princeton, J.J.Princeton University Press,1966.

Park, J.Z.; Ecklund, E.H. Negotiating Continuity: Family and Religious Socialization for Second-Generation Asian Americans. Sociol. Q. 2007, 48, 93-118

How to cite this article: Chaudhary A (2017), A Study of Modernisation among Indian Youths across Gender \& Religions, International Journal of Indian Psychology, Volume 4, Issue 2, No. 86, ISSN:2348-5396 (e), ISSN:2349-3429 (p), DIP:18.01.026/20170402, ISBN:978-1-36568609-2 